Research Article

\title{
Influence of Traditional Beliefs on Agricultural Activities of Women in Ogbia Local Government Area, Bayelsa State
}

\author{
${ }^{1}$ Nnodim, A.U, ${ }^{2}$ Obele, I .T \\ ${ }^{1}$ Department of Vocational and Technology Education, Rivers State University, Port Harcourt \\ ${ }^{2}$ Department of agricultural education Isaac Boro College of education, Sagbama, bayelsa state.
}

\begin{abstract}
The study investigated the traditional beliefs in Ogbia, and how they influence the agricultural activities of women in the area. It determined the nature and forms of these traditional beliefs, and their influence on the women involved in agriculture. A sample of 200 women were randomly selected from ten communities . The instrument for data collection was a 24 item questionnaire, titled, the influence of traditional beliefs on agricultural activities of women in Ogbia, its face validity was done by two experts in the field of community development, while a reliability coefficient of 0.75 was established using Cronbach Alpha test. 200 copies of it, were distributed to elicit responses from the respondents, while 187 copies were received and used for data analysis, using percentage and mean. The study, revealed that. Ogbia women are very religious: $\mathbf{8 5 . 0 3 \%}$ and $\mathbf{1 4 . 9 7 \%}$ are Christians and traditional worshipers respectively. It discovered that most women are into farming mainly to feed the family. It was also found that, traditional beliefs in Ogbia, prevent women from growing certain crops ,fishing in "certain" lakes, processing of some crops, farming on days regarded as sacred and taking part in some farm activities like land preparation. . The study revealed a significant negative relationship between traditional beliefs and agricultural activities of women. It was recommended that women's access to production resources such as land, credit and appropriate technologies, be improved so as to enhance their capacity in food production among others.
\end{abstract}

Key words: Tradition, Beliefs, Agriculture and Activities

\section{Introduction}

Rural women are said to be much involved in virtually all aspects of the agricultural processes despite their daily domestic chores such as meal preparation, compound cleaning and child caring. Greenidge (2000) noted that, in most subSaharan African countries, women make significant contributions to food production and the processing and marketing of foodstuffs. Women are productive partners in rural agriculture, but their contribution, is not fully recognized and harnessed. It could be argued therefore that the failure to recognize women's contribution led to the situation whereby women are denied assistance required to improve efficiency in agricultural sector ( Booth 200).

According to Kiriro (2003), in many African countries, women contributes a larger percentage of the agricultural labour force, also that between 2000 and 2030, global demand for food is expected to soar as total world population swells by 2.1 billion people and the task of producing the additional food will fall on women, especially in the developing world, who already produce 50 to 90 percent of domestic food crops in Asia, and between 80 and 90 percent in many sub-Saharan African countries. Ogunlela and Muktar (2009) noted that, the role women play and their position in meeting the challenges of agricultural production and development are quite dominant and prominent. According to the United Nations Development Programme (UNDP) (2000), women constitute 60-80 percent of agricultural labour force in Nigeria, depending on the region and they produce two-thirds of the food crops, in spite of the widespread assumption that men are the key farm managers and decisions makers. Sadly, women farmers in the country are among the voiceless, especially with respect to influencing agricultural policies.

It is noteworthy that, policies, which are aimed at increasing food security and food production, tend to either underestimate or totally ignore women's role in both production and the general decision-making process within the household. The Draft National Policy for Women in Agriculture (2008) affirmed that, women's pivotal role in agriculture has never been recognized fully. They work as female agricultural labourers, as farmers, family labourers and as managers of the farm and farm entrepreneurs.

The commonwealth Secretariat (2001) noted that, women are known to produce two-thirds of the world's food. In general, women provide 50-60 percent of the labour input, increasing to 80 percent in paddy and rice production. Due to rise in the number of female-headed households as substantial numbers of males migrate to cities, more women are becoming functional heads of both households and farming activities. Although, production of major food crops has improved in recent years, rapidly growing populations and expanding industries in many developing countries have caused a continuous increase in the demand for food and commercial crops.

Ogunlela and Muktar (2009) noted that, most farmers in 
Nigeria operate at subsistence, smallholder level in an extensive agricultural system; hence in their hands lies the country's food security and agricultural development. Particularly striking, is the fact that these women, takes the lead in agricultural activities, making up to $60-80$ percent of the labour force. It is however ironical that their contributions to agricultural and rural development are seldom noticed and, they have either none or minimal part in decision-making process regarding agricultural development. Women can therefore be seen to play a crucial role in agricultural development, yet they are perhaps the least integrated of the players in the development process. Despite their valuable contributions, the role of women in agricultural production, have been subordinate to that of men over the years. However, the challenges facing women is not only being subordinate to men, but in addition to obstacles constituted by culture and traditional beliefs of the people.

The traditional and cultural practices of people affect all aspects of their life including social relationships, contributions to societal functioning and agricultural and rural development (Asu, Gever, and Joshua, 2013). All people, no matter the race, have their beliefs and practices concerning their way of life.

Ikenga-Metuh (1987) described African traditional religion as: institutionalized patterns of beliefs and worship practiced by various African societies from the time immemorial in response to the supernatural as manifested in their environment and experience. African traditional religion is simply defined as the beliefs and practices of our forefathers which have been passed on from one generation to the other (Ushe, 2010). This definition is the most appropriate because it describes African indigenous belief system which for a long time has been labeled as ancestral cult, fetishism, animism, pantheism, savage, superstitious, primitive, native and idolatry by the Europeans.

In Africa and indeed Nigeria, the traditional belief system holds the ascription of supernatural powers to objects called gods and goddesses. The major tenet of African traditional religion and belief system lies in the belief that the abode of the gods and goddesses is located on rock, streams, pond, tress, land or anywhere they so desire to live within the community. The gods or goddess communicate its will to the people through the juju priest or chief priest. The belief system is that the gods protect the community members from harm, famine, barenness, impotence, drought, epidemics and war among others. The gods avenge their anger on whoever omits or commits any flaw for which their presence forbids; hence, the cultural system holds to a very high esteem all the precepts of the laws of the gods (Shastri, Bhat, Nagaraja, Murali, \& Ravindranath, 2002). These beliefs and strategies are passed on to those who become initiated into adulthood in the community during the rites of initiation. In the western part of Nigeria, most often, it is the men that are always initiated into these community cults or sects which are often enshrined in religious or cultural beliefs and superstitions and enforced by taboos. In the Eastern part and especially the riverine areas, it is the women who have personal gods and are initiated into a community cult or enforced by taboo. The taboos and beliefs have legal backing in the rules and institutions of the communities which are strong enough to make people obey the religious and cultural regulations (Venkataraman, 2000; Cox, 2000).

Meena (2005) states that, most African communities have had gender specific roles in agricultural production. Land clearing is normally assigned to men, while women and men participate in tilling the land. Weeding is normally done by women, who are also responsible for transporting crops from the farm to the home or to cooperative units. In terms of division of labour, studies indicated that women have been contributing more time in the agricultural cycle than men. The contribution of women could therefore be said to be very significant, but in most cases taken for granted. Statistics could have also unwittingly assigned women's contribution a zero valuation with their labour regarded merely as "unpaid family contribution.

According to Ojua (2013), these traditional beliefs include restrictions of women to own farmlands, reliance on a particular deity to achieve good harvest, and existence of taboos for women to grow certain crops or fish in certain ponds. Such belief system, discriminates against women inspite of the fact that most women have the capacity to contribute to agricultural and rural development.

Asu, Gever, and Joshua (2013) studied African cultural practices and health implications for Nigeria rural development. They concluded that some of these practices are negatively affecting the lives of women and children and that cultural change and continuities in various angles will go a long way through enculturation to ensure that some of these negative practices are destroyed and new positive ones are enhanced.

There is therefore a need for community dialogue to actively engage rural women in agricultural development so that they do not end up as passive receptacles of development decision making (Akpotor, S \& Imoh, G., 2009).

Women in Ogbia local Government Area have the capacity to contribute meaningfully to agricultural and rural development, but the reverse is the case. Could this be as a result of certain traditional practices that exist, and hinders them from carrying out certain agricultural activities or exploiting them to the fullest?

In light of the above, this study ascertained the traditional beliefs in Ogbia Local Government Area and the extent to which they restrain women from achieving their full potential in agricultural and rural development activities

\section{Purpose of the Study}

The main purpose of this study is to determine the influence of traditional beliefs on agricultural activities of women in Ogbia Local Government Area of Bayelsa State.

Specifically, the objectives are therefore to:

1 Examine the demographic characteristics of women in Ogbia local government area. 
2 Identify the traditional beliefs among Ogbia people in Ogbia local government area.

3 Determine the influence of traditional beliefs on women's involvement in agricultural activities

\section{Research Hypotheses}

Ho: The traditional beliefs in Ogbia, do not have any significant relationship with the activities of women in agriculture in the area.

\section{Methodology}

The researcher adopted the co relational survey design in the study, conducted in 10 communities of Ogbia Local Government Area of Bayelsa State, Nigeria. The population of the study comprised of 1254 registered women farmers in the area (MANR/BYS, farmers census 2012). Purposive random sample technique was used to select 20 respondents each from 10 communities in the area, making a total of 200 respondents for the study. The factor in consideration was the age of the respondents, as it also determines their level of farming experience. Primary data were collected through the use of well structured interview schedule guided by a 24 item questionnaire designed in the Likert pattern of 4-point rating scale of agreement. The instrument was given a face validity by two experts in the field of community development and subjected to reliability test using Cronbach alpha, yielding a score of 0.75 . A total of 200 were distributed to respondents in the area, while 187 were retrieved and used for data analysis.. Descriptive statistics such as percentages and frequency distribution, mean and standard deviation were used to analyze qualitative data from the study. The decision was guided by a criterion mean of 2.50 and the midpoint for decision is 2.5. Pearson product moment correlation coefficient was used to test the hypothesis.

\section{Results}

\begin{tabular}{lcc}
\hline Age of respondents & Frequency & Percentage \\
\hline Below 30 years & 15 & 8.02 \\
30 to 40 years & 61 & 32.62 \\
41 to 50 years & 83 & 44.39 \\
51 years \& above & 28 & 14.97 \\
Total & $\mathbf{1 8 7}$ & $\mathbf{1 0 0}$ \\
Marital status & & \\
Single & 27 & 14.44 \\
Married & 100 & 53.48 \\
Widow & 32 & 17.11 \\
Separated & 28 & 14.97 \\
Total & $\mathbf{1 8 7}$ & $\mathbf{1 0 0 .}$ \\
Religion & & \\
Christianity & 159 & 85.03 \\
Muslim & 0 & 0.00 \\
Traditional Religion & 28 & 14.97 \\
Total & $\mathbf{1 8 7}$ & $\mathbf{1 0 0 .}$
\end{tabular}

Educational Attainment

$\begin{array}{ll}\text { No formal Education } & 114 \\ \text { Primary } & \\ \text { Secondary } & 17 \\ \text { Tertiary } & 9 \\ \text { Total } & \end{array}$

114

60.96

47

17

9

100

\section{Farming experienc}

\begin{tabular}{lcr} 
below 10 year & 8 & 4.28 \\
11 to 20 years & 25 & 13.37 \\
21 to 30year & 88 & 47.06 \\
31 years and above & 66 & 35.29 \\
Total & $\mathbf{1 8 9}$ & $\mathbf{1 0 0}$ \\
Income level & & \\
Less than 10,00 & $\mathbf{1 5}$ & 8.02 \\
N10,000 to20,000 & 61 & 32.62 \\
N21,000 to30,000 & 83 & 44.39 \\
Above N30,000 & 28 & 14.97 \\
Total & 187 & 100 \\
\hline Source : Field survey $\mathbf{2 0 1 8}$ & of Women in \\
Table 3.1 Demographic Characteristics & \\
\multicolumn{2}{l}{ Ogbia. }
\end{tabular}

Table 1 above shows the distribution of respondents according to age, marital status, religion, educational level, farming experience and level of income. $53.48 \%$ of respondents are married, however, there is a sizeable proportion $32(17.11 \%)$ who are widowed, while $14.97 \%$ are separated, leaving the smallest proportion of $27(14.44 \%)$ as single. The table also showed that $85.03 \%$ and $14.97 \%$ are Christian and Traditional religions respectively. On educational background of the respondents, $60.96 \%$ of the respondents had no formal education, $25.13 \%$ had primary education, while $9.09 \%$ and $4.89 \%$ had secondary and tertiary education respectively. For farming experience, the findings showed that $47.06 \%$ of the respondents had being in the occupation for 21 to 30 years, $35.29 \%$, above 30 years, $13.37 \%$ for 11 to 20 years, while only $4.28 \%$ had done farming below 10 years. On the income level of the respondents, the table also showed that only $14.97 \%$ of the respondents, obtain income above N30,000 monthly,44.39\% are between 21,000 to \#30,000 monthly, $32.62 \%$ gets between 10,000 to \#20,000 monthly and 4,02\% gets less than \#10,000 monthly income.

\begin{tabular}{|c|c|c|c|}
\hline Items & $\mathbf{X}$ & SD & Remark \\
\hline $\begin{array}{l}\text { It is a taboo to farm in } \\
\text { certain days of the week }\end{array}$ & 3.44 & 0.64 & Accepted \\
\hline $\begin{array}{l}\text { Some lakes are sacred } \\
\text { and women cannot fish in } \\
\text { them }\end{array}$ & 3.41 & 0.77 & Accepted \\
\hline $\begin{array}{l}\text { Certain bushes and forest } \\
\text { cannot be cultivated by }\end{array}$ & & & \\
\hline women & 3.56 & 0.67 & Accepted \\
\hline $\begin{array}{l}\text { Tradition forbids women } \\
\text { from inheriting land in } \\
\text { the area }\end{array}$ & 3.60 & 0.57 & Accepted \\
\hline $\begin{array}{l}\text { In communal land } \\
\text { ownership, women are } \\
\text { not given land }\end{array}$ & 3.43 & 0.74 & Accepted \\
\hline
\end{tabular}


Women are forbidden

from cultivating certain

crops

Some agricultural plants

cannot be harvested by

women

Some agricultural

practices are exclusively

for men

It is difficult for woman

to secure credits without

male guarantor

Traditionally, women are

not encouraged to join

certain professional

organization

Grand Mean

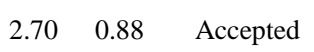

$3.40 \quad 0.73 \quad$ Accepted

$3.44 \quad 0.72 \quad$ Accepted

$3.40 \quad 0.640 \quad$ Accepted

$3.65 \quad 0.571 \quad$ Accepted

3.78

\section{Source: Field Survey, 2018}

Table 2: Mean response on traditional beliefs that restrain women from agricultural activities

Table 2 above summarized ten instruments used in measuring nature of traditional beliefs that restrains women from agricultural activities in Ogbia. The highest mean rating score of 3.647 were gotten for the assertion that tradition forbids women from inheriting land and lack of encouragement for women to join certain professional organizations in their communities, while the lowest is 2.770 from the belief that women are forbidden from cultivating certain crops, 3.556 for the assertion that certain bushes and forest cannot be cultivated by women, while 3.444 are for taboo to farm in certain days of the week and difficulty for women to secure credit without male guarantors. The assertion that some agricultural practices are exclusively for men had 3.439 as mean, 3.428 for the assertion that women are not given land in communal land ownership, 3.406 for the assertion that some lacks are sacred and women cannot fish in them, and 3.401 for the belief that some agricultural plants cannot be harvested by women. The mean rating scores for all the instruments on the table are above 2.50 , hence they are all accepted.

This result is corroborated by Tegegne (2012) who conducted a study to assess the sacred events in agriculture in southern nation nationality people's region: the case of Halaba special Woreda, Ethiopia. The study found that rural women spend their time at home during such days, while productive activities, which directly benefit their families and society in economic terms, are carried out on normal days. The study also found out that in Halaba, rural women are involved in food processing, water and fuel wood collection, assisting family farm, marketing and labor exchange for community services.

\begin{tabular}{llll}
\hline Item & X & SD & Remark \\
\hline
\end{tabular}

Lost of man hours

to traditional

$\begin{array}{llll}\text { activities } & 3.26 & 0.84 & \text { Accepted }\end{array}$

Limits

$3.43 \quad 0.70 \quad$ Accepted

entrepreneurship

capacity of women

Low level of agric

productivities

among women

Poverty

High dependency

on their spouses

for survival

3.010 .85 Accepted

$2.55 \quad 0.75 \quad$ Accepted

Poor participation

in agricultural

extension services

Lack of access to

agricultural inputs

and credits

High level of

resistance to

change by women

$3.29 \quad 0.82 \quad$ Accepted

$3.24 \quad 0.95 \quad$ Accepted

$3.20 \quad 0.89 \quad$ Accepted

$3.01 \quad 0.94 \quad$ Accepted

\section{Source: Field survey 2018}

Table 3; mean response on influence of traditional beliefs on agricultural activities of women

Table 3 shows how traditional beliefs influence women's role in agricultural activities in Ogbia local government area of Bayelsa state. As shown in the table, the mean responses are greater than 2.50 for all the instruments. The lowest mean score of 2.545 is poverty as an influence and 3.428 as the highest on the influence that it limits the entrepreneurship capacity of the women,. Others scores are 3.294, for high dependency on their spouses for survival, 3.257 for lost of man hour to traditional activities, 3.241 for poor participation in agricultural extension services, while 3.203 stood for lack of access to agricultural inputs and credits and 3.011 for high level of resistance to changes by the women in the area.

This result is in consonance with the result obtained by Apata and Awe (2013) who conducted a study to examine traditional beliefs and practices of women involvement in agricultural activities in south-western Nigeria. The study found traditional beliefs and practice of the people to affect women's role in agriculture. Also, Mamah (2011) in similar study conducted in Igbo Eze South Local Government Area, Enugu State found culture of the people to highly affect female participation in agriculture and community development.

This result is also in line with the result of Ajadi, Oladele, Ikegami and Tsuruta (2015) who conducted a study to ascertain the rural women's farmers' access to productive resources: the moderating effect of culture among Nupe and Yoruba in Nigeria. The result reveal women were restricted from major decision making process.

Relationship between Traditional Beliefs and the socioeconomic characteristics of women in Ogbia

The relationship between traditional beliefs and the activities 
of women in agriculture in Ogbia is resolved by subjecting the variables to Pearson correlation coefficient analysis. We hereby recall the hypothesis earlier stated:

Ho: The traditional beliefs in Ogbia do not have any significant relationship with the agricultural activities of women in the area.

This hypothesis was tested by subjecting data on traditional beliefs in Ogbia with that of the influence on the agricultural activities of women in the area. Table 5 below gives the result of analyzing with Pearson Product Moment Correlation coefficient statistical tool.

\section{Correlations}

\begin{tabular}{|cl|l|l|}
\hline & $\begin{array}{l}\text { Traditional } \\
\text { Beliefs }\end{array}$ & $\begin{array}{l}\text { Influence } \\
\text { on agric, } \\
\text { activities }\end{array}$ \\
\hline Pearson & 1 & $-.395^{* *}$ \\
Correlation & & .007 \\
& Sig. (2-tailed) & & 187 \\
& Pearson & 187 & 1 \\
Influence on agric. Correlation & $-.395^{* *}$ & \\
activities of women & Sig. (2-tailed) & .007 & 187 \\
N & 187 & \\
\hline
\end{tabular}

**. Correlation is significant at the 0.01 level (2-tailed).

Source: SPSS ver. 20.0 Output window

4.5: Result of Pearson product moment correlation coefficient for Traditional Beliefs and influence on agricultural activities of women.

\section{Result Interpretation}

Traditional belief is correlated with the influence on the agricultural activities of the women, yielding a negative coefficient of -0.395 , and a p-value of 0.007 , which shows that there is a weak but negative linear relationship between the two variables. Direction is opposite, meaning that as one increases the other decreases. We also infer from the p-value $(=0.007)$ which is less than the level of significance, alpha $(\alpha$ $=0.05$ ), and therefore reject the null hypothesis to conclude that there is significant correlation between the two variables: Traditional Beliefs and their influence on the agricultural activities of Ogbia women in Bayelsa State.

\section{Conclusion}

Based on the findings of the study, it is concluded that women in Ogbia have low demographic characteristics, they play key role in agricultural development. They however, have restrictions due to some traditional beliefs, which includes restriction from doing farming activities on sacred days; restriction from fishing in certain lakes; restriction from farming in certain forest/bush; restriction from owning farmland, restriction from cultivating certain crops; restriction from membership of some organizations, restriction from attending long hours meeting, especially outside their communities not being allowed to do certain cultural practices in crop production; restraint from holding leadership position in community development activities and restriction from taking part in major decision making exercise. Sadly, these restrictions have led to low level of agricultural productivity, limited access to credit facilities; low income, reduction in types of crop produced in the area, high level of resistance to innovations and poor participation in agricultural extension, among others.

\section{Recommendations}

Based on the findings of the study, the following recommendations are made:

1 Women should be encouraged and incorporated to fully participate in decision making process, especially in agriculture and local leadership in Ogbia. This will enable them air their views and make noble contributions to the development of agriculture in the area. This will have a direct impact on their social status.

2 Traditional rulers, chief and elders should be encouraged through regular consultations, on the need to eradicate some of the beliefs with negative influences of the activities of women in the area.

3 The need to allow women to participate in agricultural extension programme should be seriously considered by chiefs and traditional rulers in the study area.

This will have a direct literacy benefit on the women, which will translate to better agricultural practices

4 Orientation programmes should be organized in the study area to sensitize community members on the need to change some of the negative beliefs held against women. This could enhance a reorientation about the activities of women and consequently give rise to increase participation and high productivity.

\section{References}

[1] Akpotor, S \& Imoh, G.(2009). "The Millennium Development Goals": Issues of Gender, Women, Poverty and Development." Faculty of the Social Sciences, Delta State University, Abraka, Publisher

[2] Asu, O.T., Gever, I.D., \& Joshua, N.T. (2013). African Cultural Practices and Health Implications for Nigeria Rural Development. International Review of Management and Business Research 2(1)pg 23

[3] Carswell S (2003). A family business women, children and small holder sugar-cane farming in Fiji. Asia pacific viewpoint, 44(2): 131,

[4] Cox P.A. (2000). Will tribal knowledge survive the millennium? Science 287:44-45.

[5] CTA, (1993). A Woman's rightful place? SPORE (b1monthly bulletin) technical Centre for agricultural and rural Co-operations (CTA) Netherlands, No 4, April.

[6] Ehizuelem, J. E. (1996). Theories of Development and Underdevelopment, Benin City University of Benin,.

[7] FAO (1995). Women, Agriculture and Rural Development in the near East: Findings of an Food and 
Agricultural Organization study, Food and Agricultural Organization, Rome, Italy.

[8] FAO, (1987). Pioneering a New Approach to Communication for Rural Development in Mexico: A Review of Experience: http://www.fao.orgiflocres. Retrieved on $25^{\text {th }}$ March 2017 http://www.fao.orgiflocres.

[9] Goring, R. (1992). Dictionary of Belief and Religions. Ware, Herefordshire: Wordsworth Reference.

[10] Greenidge, C. B (1999) "Forward" in The Role of Women in Agricultural and Rural Development: Promoting Income-Generating Activities, Summarry Report of a Seminar, technical Centre for Agricultural and Rural Cooperation, Athens, Greece, 18-22 October 1999.

[11] Idowu, B. (1973). African Traditional Religions: A Definition. London: SCM Press Ltd.

[12] Jibowo, G (2000) Essentials of Rural Sociology, Gbemi Sodipo Press Ltd. Nigeria. Benin City

[13] Ikenga-metuh, E. (1987). Comparative Studies of African Religions Onitsha: Imico Publishers.

[14] Kiriro, P (2003) "Farmers and Food Security" A Paper Presented at the IFA-FAO Agriculture Conference on Global Food Security and the Role of Sustainable Fertilization, Rome, Italy 26-28 March, 2003.

[15] Meana, R (2005) "Women and Sustainable Development" in United Nations -- Non -Governmental Liaison Services No. 5 Downloaded 12/29/2005 www.unsystem.org/ngls

[16] Miller, R. (1981), "Towards a Negotiating Model in Rural Development", Development Digest, 1, (1) 69-75 Middleton J. (1981). "IEC Planning: Eight State of the Art Principles". Development Communication Report. No. 44.

[17] Ogunlela, I. O \& Muktar, A.A (2009) "Gender Issues in Agriculture and Rural Development in Nigeria: The role of Women" in Humanity and Social Sciences Journal 4 (1): 19-30, IDOSI Publishers

[18] Ojua, T. A. \& Omono, C. (2012). African Sacrificial ceremonies and issues in socio-cultural Development. British Journal of Arts and Social Development, 4: 1.

[19] Rim-Rukeh, A., Irerhievwie G., \& Agbozu, I. E. (2013). Traditional beliefs and conservation of natural resources: Evidences from selected communities in Delta State, Nigeria. International Journal of Biodiversity and Conservation. 5(7), 426-432,

[20] Shastri C.M., Bhat D.M., Nagaraja B.C., Murali K.S., \& Ravindranath N.H., (2002). Tree species diversity in a village ecosystem in Uttara Kannada district in Western Ghats, Karnataka. Curriculum. Science 82:1080-1084.

[21] Ushe, M. N. (2005). Between Continuity and Change: A Comparison of Tiv and Christian Concept of Death and Burial Rites. Unpublished Doctorate Dissertation, Department of Religious Studies, University of Jos. 